\title{
CONTRASTING REPRESENTATIONS OF ENGLISHNESS DURING FIFA WORLD CUP
} FINALS

\section{TOM GIBBONS University of Teesside}

\begin{abstract}
Football and English national identity have been interlinked for over a century. The increased display of the St George Cross rather than the Union flag when the England team compete in international football competitions has been linked to a rise in a specifically English national consciousness. Academics have assumed this to be a response to advancing European integration and political devolution within contemporary Britain without providing much empirical evidence for such claims. However, evidence from qualitative discourse analysis of British daily newspaper coverage of FIFA World Cup Finals suggests that Englishness has always been banally depicted as a multifaceted concept in relation to football. First, Englishness has long been and still is used to refer to Britishness and vice-versa in World Cup coverage. Second, World Cup football correspondents have often referred to strongly felt regional and local divisions within Englsh society that co-exist with the idea of an overarching English national consciousness. This paper forms part of a wider investigation into the complexities of defining Englishness through football fandom practices.
\end{abstract}

\section{Introduction}

The main point of this essay is to provide empirical evidence to suggest that Englishness has been banally depicted as a multifaceted concept throughout the history of the England national team's involvement in the FIFA World Cup Finals tournament. This is achieved through an analysis of British national press coverage of tournaments the England team have qualified for. The main focus is on tournaments since 1966, but some evidence from previous tournaments is also briefly drawn upon. The FIFA World Cup was chosen above any other international football competition because the English national team has played a total of fifty-five games in twelve tournaments and this is more than they have played in any other international tournament against opposition from outside of the British Isles.

\section{Football fandom as an articulation of English national identity?}

Football and English national identity have been interlinked for well over a century. The English formally codified the modern sport of football after the formation of the first Football Association (FA) in London in 1863. The sport was globalised, initially through British Imperialism, from the late nineteenth century. Football has also helped maintain national divisions within the 'United' Kingdom largely through having separate national governing bodies (Football Associations) for England, Scotland, Wales and Ireland since the late nineteenth century and for Northern Ireland after the division of Ireland in 1921. [1]

Although the team only consisted of amateurs, England's first international football match was a friendly against Scotland in 1872, but they did not play teams from outside of the British Isles until a friendly against France in 1906. Although a team of England amateurs represented Great Britain in the 1908 Olympics football competition, England's first appearance at a serious international tournament as a non-amateur team was in 1950 against Chile in the already twenty-year-old FIFA World Cup Finals tournament. [2]

It cannot be denied that other popular sports have a long history of English involvement at the international level and have also captured the English national imagination. The first England rugby union international was in 1871 against Scotland and the first England test cricket international was against Australia in 1877. [3] Yet football has always held a special place as England's most popular national sport. There is no other mainstream sport in which a non-amateur national team have only specifically represented 
England in serious international competitions. [4] In rugby both British and English national teams have competed in major international fixtures since the late nineteenth century. In cricket, the England team also represent Wales and have always included Welsh players, as well as some Scots. [5]

A British national football team has never competed in the World Cup Finals or European Championships, which have been the most regular and longstanding international football tournaments. Football has thus long been a significant site for competing articulations of English national identity on the part of the FA, the British media as well as many football fans. [6] The heightened appearance of the St George Cross around international football tournaments is often claimed to have begun around the 1996 European Football Championships (Euro 96). This practice has been regarded as a specifically English, rather than British, cultural response to the most recent wave of European integration and related political devolution of the 'Celtic' nations within Britain. [7]

The enhanced political power gained by Scotland and Wales (Northern Ireland being more complicated), which directly followed the introduction of a new Labour government in 1997, was arguably the result of the desire of 'Celtic' politicians and many of the voting population for their respective nations to be recognised, as far as possible, as European nations in their own right, marking their heightened level of distinction from the traditionally more powerful oppressors within Britain - England. [8] Cultural representations of Scottish and Welsh national identity have also seemingly become more prominent since devolution, perhaps most clearly in the more significant displays of the Scottish Saltire of St Andrew and the Welsh Dragon. People of both nations often prefer to use these cultural symbols over and above or alongside the Union flag, which was supposed to symbolise that Britain was a 'United' Kingdom. [9]

However, there is little evidence to suggest that football fans now use only the St George Cross to signify English national identity, nor is there much evidence to suggest all football fans use this symbol to portray a unified national consciousness. In addition, Abell et al suggest that English football fans' articulations of support for the national team do not even necessarily represent their wider feelings of national sentiment. [10] More empirical evidence is required to help determine the meaning of football fandom practices to the articulation of English identity.

With this lack of evidence in mind, Gibbons and Lusted conducted online questionnaire and participant observation studies of English fans during the 2006 World Cup Finals tournament. Findings revealed that many fans chose to display their local identities whilst supporting the England team by (among other practices) branding the St George Cross flag with their club team emblems or local town/village names. Also, some fans did not only use the St George Cross to symbolise support for the England national football team, they preferred to use the British Union flag instead. [11] Therefore, this case study illustrated the multifaceted ways in which English fans articulate their national identity via football today. Yet the relationship of such fandom practices to English national sentiment still needs to be determined. It is only through taking an account of representations of English fandom practices in the past that those in the present can begin to be examined with confidence. The provision of such historical evidence was the primary purpose of the current study.

\section{Methodology}

By the mid-twentieth century the British national press was still the key source of information on football and other sports. Competing media - radio from the 1930s and television from the 1950 s - stimulated a thrust in the extent and quality of sports coverage, in the popular press in particular, from the 1930s. [12] New specialised football correspondents helped to highlight the political, social and financial aspects of the game to football fans from the late 1940s, especially in the more popular tabloids and middle-market papers, but also with Geoffrey Green writing in the quality paper The Times from 1946. [13] Yet, the relationship between what football fans read in the daily national press and their displays of national identity lacks investigation. 
Data was gathered for the current study from a number of mainly London based versions of daily national newspapers including: The Guardian, The Times, The Independent, The Daily Telegraph, Daily Mail, Daily Mirror, Daily Express, The Sun as well as their some of their Sunday sister papers. The main focus was on the more 'popular' rather than 'quality' national dailies including The Sun, Daily Express and the Daily Mail, which currently account for around eighty per cent of UK newspaper readership figures and require more thorough historical study according to Crolley and Hand. However, it is important to state here that these three newspapers have not always enjoyed such high readership figures and their popularity fluctuated significantly over the latter half of the twentieth century. For instance, the Daily Mirror was the highest seller in the 1950s and was outselling The Sun (which appeared from the 1960s) up to the early 1980s according to Seymour-Ure. [14] Nevertheless, these papers have been chosen as the main focus for their continuity and consistency in print over the majority of the time period analysed, rather than for their popularity at specific points. As such, it is likely that the sample analysed incorporates at least some of what many football fans (who read national newspapers) will have been reading themselves during each of the World Cup Finals tournaments studied.

The qualitative discourse analysis employed in the current investigation is broadly congruent with previous studies of British newspaper coverage of the England team in international competitions. [15] Other than Crolley and Hand's investigation of football coverage in The Times throughout the twentieth century and Chisari's analysis of The Times during World Cup Finals between 1930 and 1970, all of these studies have centred on press coverage of Euro 96 or more recent international competitions. [16] Yet, England has been involved in the FIFA World Cup for longer than any other major international football tournament. [17] Although the main focus has been on World Cups since 1966, all of the fifty-five matches the England team have played during each of the twelve World Cup Finals tournaments they have qualified for have been drawn upon to some extent in the current research study.

Bignell contends that news discourse consists of ideological representations of the world because it selects what will be reported and sets terms of what will be significant. Billig recognises that these representations, although not overt, still act to 'flag the nation'. He argues that it is by continual reference to national symbols and aspects of a nation's history, such as successes in wars, that banal nationalism occurs. In this regard Billig contends: 'Small words, rather than grand memorable phrases, offer constant, but barely conscious, reminders of the homeland, making 'our' national identity unforgettable.' [18]

Billig's work not only recognises the important role of the British print media in 'flagging the homeland daily', but also the importance of sport in this regard: 'all the papers, whatever their politics, have a section in which the flag is waved with regular enthusiasm. This is the sports section'. [19] Such sentiments in relation to both the role of the British national press and sport are echoed by Edensor who contends that: 'Probably the most currently powerful form of popular national performance is that found in sport... These everyday and spectacular contexts provide one of the most popular ways in which national identity is grounded.' [20]

Although they broadly agree with Billig's contentions, Rosie et al argue that it has often only been assumed that the mass media are central to the reproduction and evolution of national identity, rarely has this been empirically demonstrated. [21] The current study seeks to provide such empirical evidence in relation to media representations of English national identity. Findings have been divided into two broad sections that demonstrate the two main ways in which English national identity has been represented by the British national press in their coverage of the England team during World Cup Finals tournaments.

\section{The (con)fusion of Englishness with Britishness}

Jones and Kumar both suggest that Englishness has been synonymous with Britishness for so long that any distinction between the two has become very difficult. [22] Although Holt has urged that this has often been reinforced through sport, there are also examples in non-sport 
literature that draw upon the actions of football fans to help explain the fusion between Englishness and Britishness. [23] Even though England have played national teams representing the other 'home nations' on multiple occasions since at least 1872, the form of English nationalism portrayed within the sporting press around international football has often been associated with Britain. Crolley and Hand discuss how The Times depicts the symbolic nature of Wembley stadium to conceptions of a British-based English national identity since the 1920s. Moreover, evidence is provided from The Times on how the effects of the decline of the British Empire, devolution and the rise of the European Union meant, 'Union flags ... were to give way to the flags of St George during the 1990s as an 'English' and 'post-British' consciousness increased,' yet how, 'the 'new' national identity actually resembles very closely the way in which the old was portrayed in the press'. [24]

..red/white and blue': $1950-1966$

First, it is important to note that the evidence gathered in relation to World Cup Finals before 1966 is nowhere near as comprehensive as that for 1966 and beyond. Therefore, the majority of extracts mentioned in this section are from 1966, with a few snippets from coverage of previous tournaments that are early examples of themes later evident in 1966 and beyond.

Between 1950 and 1966 there were very few overt visual depictions of English national identity in the World Cup coverage analysed. However, when there was a national symbol in the background of a photograph, or illustrated in a cartoon, it was always the British Union flag or the Three Lions badge, never the St George Cross. References to the England team as British were apparent from the very first World Cup Finals England were involved in. For example, Frank Butler, football correspondent for News of the World, asks 'Why doesn't somebody think of fixing a Union Jack to the motor coach driving the England team to Games'. [25] In 1954 there were assumptions that England were being supported by all of Britain, despite the fact the Scots were playing in the tournament too. For example, in the Manchester Guardian a journalist recalls: ' ...cheered on by about five thousand British visitors, England could do much to rebuild her tottering prestige', before their opening match against Belgium. [26]

As one might expect, there were also many references to the British crown, the Second World War, as well as British institutions in the papers analysed during these early World Cup Finals tournaments. Sir Stanley Rous (secretary of the English FA from 1934 to 1962; president of FIFA from 1961 to 1974) is depicted in a cartoon from the Daily Express during the 1958 World Cup as 'imagining he's Winston Churchill' and Walter Winterbottom (England Manager 1947-62) 'convinced he's Monty' - referring to the legendary British General Lord Montgomery. [27] Even though all the home nations were involved in this tournament, England were seen as the most important representatives of the whole of Britain. The Daily Express, Daily Mail and the Manchester Guardian reported on the fact that the British Royal Navy were amongst the spectators cheering on England, yet their presence was not noted in reports on the other home nations games. [28] Also, stories on the other home nation's matches were often amalgamated into those on the English team - usually at the bottom - and it was claimed that English influences on the other British teams were behind their success when they played well or won. [29]

Later during the 1962 World Cup writing in the Daily Express about England's loss to Brazil, Desmond Hackett makes reference to his own British version of Englishness: 'England were out after 14 minutes of the second half. An unforgettable goal that even red/white and blue Hackett could not grudge'. [30] These brief examples illustrate the importance of England's loyalty to British traditions and institutions during early post-war period World Cup Finals tournaments. According to Paxman the English have always put their faith in British institutions. [31]

Moving on to 1966, where coverage in all newspapers analysed undeniably increased from that in previous World Cups, even in reports of the final match where England won the cup beating West Germany 4-2 after extra time there are hardly any 
national symbols evident - be they British or English. One of the few found was a cartoon from the Daily Express depicting screaming England fans, with one fan praying: 'Come on England. WIN, if only to take my mind off the Pound!' The only national symbol visible is a fan flying a Union Flag in the top right hand corner of the picture. The fact that the England team's success is being associated with the British state economy suggests that football was even then a reflector of social trends. [32] Later, the Daily Express printed a cartoon which perhaps acts as a potent symbol of this 'golden age' for English football. Yet it depicts both British and specifically English symbols. The cartoon shows the England captain, Bobby Moore, holding a football, sporting his red England shirt with the three lions badge on its breast. In the background, the World Cup trophy looms large over Wembley stadium, from which chants of, 'England! England...England!' are rising high into the sky. Though, even in this cartoon, the two flags on top of the towers of the former Wembley are British Union flags, rather than more English St. George Crosses or Three Lions. [33]

Even though the commercial mascot of the 1966 World Cup finals was an English lion named 'World cup Willie', he incongruously sported a shirt (usually a waistcoat) with a Union flag in its design, rather than the more specifically English red cross of St George. Crolley and Hand posit that World Cup Willie was used to symbolise the national character of the English - bravery, courage and tenacity - characteristics associated with King Richard I 'The Lion-Heart' (1157-99). His death in battle against France during the Third Crusade was what made him an English legend. [34] According to Barraclough the first Royal Standard was that of King Richard I, which was flown in 1189, almost one hundred years before the Cross of St George. The Royal Standard is partially comprised of the same three lions emblem that has always been depicted on the England national football team's shirt making it just as specifically English as the St George Cross. [35] Although the mascot was mentioned in a number of newspaper articles analysed in the current study, the fusion between English and British symbols within its design was never highlighted suggesting that English and British were regarded as synonymous terms during this period.

Furthermore, the England defender Nobby Stiles was often referred to as, 'the little Lionheart', in many of the newspapers studied over World Cup 66. For example in the Daily Express Stiles epitomises the English national character through being associated with the mythical legend of King Richard I in England's past. [36] This is interesting considering Stiles' playing style was often reported on as being attune with a national standard that was associated with the British. For instance: 'Stiles will never be a gentlemanly footballer'. [37] However, this is not surprising considering the English have long associated themselves with British Victorian and Edwardian ideas such as the amateur-gentleman ideal, and this national characteristic of the English has never been one which they felt they needed to explain. [38]

During the 1966 World Cup clear links to the war were still being made by many journalists. For example, The Sun printed a cartoon depicting an army flying the Union flag on their way to Wembley stadium for the final match between England and West Germany the caption beneath read: 'Auf weidersehen, mein Liebling - we are all being posted to Wembley'. [39] In the written text of some of the articles analysed there were again signs which highlight the significance of the England players' loyalty to the British crown. For example, England players were expected to stand facing the Queen and other members of royalty present at Wembley whilst singing 'God Save the Queen' both before and after their matches. Yet, after the first game versus Uruguay some players left the pitch almost immediately after the match. This was highlighted by many newspapers as a mark of disrespect towards the British head of state. An article in The Sun stated, 'England men in mix-up over anthem...Four England players walked off the pitch without waiting for the National Anthem after the opening World Cup soccer match at Wembley last night...The Queen and Prince Phillip watched the game - and the anthem mix-up'. [40]

The England team were again often depicted as the sole representatives of a 'United' Kingdom during this competition. The FA secretary at the time, Dennis Follows, was quoted as saying of Alf Ramsey, 'no one will ever really be able to repay him for the riches he has brought to English - no, British - soccer', as if saying 'English' was not enough. [41] 
So it was apparent that England and Britain were quite often fused in the World Cup coverage analysed between 1950 and 1966, albeit in a largely banal fashion and although most evidence comes from the 1966 World Cup. Although national flags were not often blatantly apparent, the appearance of other national symbols and descriptions used by journalists acted as subtle 'flaggings' of a British-based Englishness. There is no question that the football fan reading these newspapers was continually reminded that England was synonymous with Britain. Although this is not that surprising considering the majority of the UK population are English, the point here is that an Englishness without reference to Britain was never articulated at this point in time. However, this began to alter somewhat in coverage of World Cup Finals between 1970 and 1990.

\section{'The paper that supports our boys': 1970-90}

The Euro 96 tournament held in England is widely considered to be the time when the majority of English football fans reclaimed the St George Cross flag from a minority of far right wing political groups such as the BNP and the National Front. This was largely due to the tournament being held on the thirtieth anniversary of the 1966 World Cup win and because England played Scotland for the first time in the group stages of a serious international football tournament which meant that the Union flag was somewhat redundant as it would symbolise the union between both nations, rather than their individual national characters. [42] However, more specifically English references began to emerge through popular press coverage of World Cups as early as 1970 . This became much more regular by the time of the 1990 World Cup and therefore before the Euro 96 tournament. Due to England's success in 1966, the fate of the national team was being displayed as a specifically English source of national pride from the 1970s. In the 1970s the tabloids and middle-market papers in particular began to make the fate of the England team front page news. Some evidence even suggests that the specifically English St George Cross was used by football fans long before the mid-1990s. [43]

England's success at reaching the semi-finals of the 1990 World Cup was reported to be so popular that it was interfering with English school children's revision for their GCSE exams, and even spicing up the English nation's sex life and reducing the number of suicides by 20 per cent. [44] The specifically English St George Cross was also apparent in tabloid and middle-market newspaper coverage of the 1990 World Cup. For instance, in The Sun there is a photo of Gary Lineker in action against the Netherlands with St. George Cross flags clearing evident in the crowd. [45] Therefore, in the 1990 World Cup, it was not only Union Jacks that filled the spaces as was reported in evidence from the quality press by Crolley and Hand and assumed by King. [46] Perhaps the most obvious example of depictions of English fans which suggests they were using the specifically English St George Cross along with the more British Union flag, was in photos of the masses of fans crowding around England's double-decker bus as it toured London on Sunday 8 July after the England team had been knocked-out of the competition. [47] Furthermore, the St George Cross also appeared in advertisements in The Sun during the 1990 World Cup Finals. Coral bookmakers used this national symbol to represent England and the St Andrews' Saltire to represent Scotland in their group stage matches and again on the day of England's famous semi-final game against West Germany. In all advertisements found before this time, only the Union flag or the Three Lions were used to represent England. [48]

Yet, this form of Englishness portrayed through the success of the national team was still often confused with Britishness in a number of ways. The evidence found in this study partially supports that from other authors who have analysed newspapers and crowd photos during the 1982 and the 1990 World Cups which suggests that depictions of Englishness were still overwhelmingly associated with Britishness. The Union flag was the most common symbol seen amongst football crowds in 1982 and 1990 according to King as well as Crolley and Hand. [49] Furthermore, Crolley and Hand state that the British bulldog was used as the official mascot for the England national team in 1982 at a time when it was also being used by the right-wing political party the National Front. The Bulldog was again used in England 
football paraphernalia around the 1990 World Cup. [50] However, a real bulldog called Winston, clearly a reference to the British wartime Prime Minister, was the England team's mascot during the 1970 tournament, and this was apparent within the written football news in The Times and illustrated in a photograph in the News of the World. [51] This suggests that the England team were being associated with this British symbol almost a decade earlier than Crolley and Hand suggested.

In addition, links between the fate of the England team and British politics were often made. In 1970 for instance, the front page of the Daily Mail on Monday 8 June included a headline which read, 'The 10 vital days that will settle the destiny of this nation'. [52] This article referred to the last British general election in 1966 which of course also happens to be the time England won the World Cup. On the opposite side of the front page is a story on England's loss to Brazil entitled 'Down but not out'. Although no explicit comparisons are made between the two stories, the 1966 link is clear and Britain and England are tied together via football. This is reinforced later in references to the Falklands war and the English football team. For instance, The Sun's slogan at the time of the Falklands and the World Cup in 1982 was, 'The paper that supports our boys'. [53] More explicitly still, The Sun had the headline, 'FA walk out on Argies', which highlighted how FA international committee men Dick Wragg, Arthur Mullen and FA chairman Bert Millichip walked out of the stadium during the opening ceremony before the first match between Argentina and Belgium due to them being 'upset at being seated with Argentine supporters'. [54] There is nothing about the other home nations teams, even though Scotland and Northern Ireland were also competing in this tournament and no doubt made a significant contribution to the war effort, suggesting this is another example of England representing the whole of Britain as was evident in previous World Cup coverage.

Similarly in 1986, England are largely depicted as the sole representatives of Britain. For instance an article in the Daily Mail stated:

The quarter final confrontation is the first soccer match between England and Argentina since the Falklands war in 1982... and it has produced the biggest burst of patriotic fervour since that time. More than 20 million Britons are expected to watch the game on TV...Argentine supporters reportedly burned Union Jacks and unfurled a banner proclaiming 'The Malvinas are Argentine'... And as England defeated Paraguay on Wednesday there were chants of 'Bring on the Argies, we want another war'. [55]

In 1990, there were still many confusions between England and Britain. For example, the England team's World Cup logo in The Sun was a Union Jack incorporated into a number ' 90 '. This was larger and more prominent for stories relating to England versus Argentina or Germany which gave the message that these matches were a battle for Britain, not just England. Both the Falklands and the Second World War were continually highlighted by both The Sun and the Daily Mail in particular during the 1990 World Cup. For example, there were two headlines on the front page of The Sun the day before England's semi-final against West Germany which read, 'We beat them in ' 45 , we beat them in '66, now the battle of '90' and 'Herr we go again'. [56] Similarly, on the day of the match the Daily Mail also used references to war in a story entitled 'Bobby's troops retreat as feelings run high'. [57]

Another way in which the tabloids and middle-market papers built up a sense of England representing Britain was through continually referring to royalty, the British Prime Minister and the British armed forces supporting the England team. For instance, on the day after England had lost to West Germany, The Sun told of how 'The Royal Family switched on to the Big Match on telly last night. Princes William, eight and Harry, five, were given special permission to stay up. And the Queen tuned in at Buckingham Palace. Even Princess Di was kept informed of the score while she sat through a classical concert at the Palace'. [58]

Finally, during the 1990 World Cup English hooligan fans were almost always classed as 'British' in the descriptions of them in the tabloids and middle-market papers, and 
very rarely as specifically English. They were always described as 'flying Union Jacks' or 'wearing Union Jack shorts' despite the fact that many photos showed them wearing or waving the St George Cross. This could be interpreted in one of two ways: either the papers were consciously attempting to pass the responsibility for English hooligans onto the whole of Britain; or, this was simply another example of the subconscious fusion of England and Britain as though synonymous terms. If the former was the case, many journalists shot themselves in the foot by distinguishing the Scots as particularly well behaved in a number of stories. [59]

\section{'...two forms of patriotism': $1998-2006$}

The distinctively English national symbol of St. George was ubiquitous throughout coverage of the 1998, 2002 and 2006 tournaments. This has been noted by Crabbe, Garland and Poulton and was largely due to the overt display of the flag by English fans, rather than an initiative from the FA. [60] There were many examples of reports on this trend throughout all the different newspaper titles studied. An example is evident in an article in the Daily Express during the 2002 World Cup which states, with respect to St. George Cross flags specifically, that: 'In 1966 there were just 12 flag companies in Britain. Now there are 551 with an expected turnover of $£ 100$ million. Fans have so far snapped up 30 million flags'. [61] Later, prior to the 2006 World Cup an article in The Observer claimed 'The red cross on a plain white background is by far the... most in demand item, outselling the Union flag by about three to one'. [62]

However, in the same way as that evident in the newspapers studied for previous World Cups, the English character in coverage of these more recent tournaments was often defined by references to British achievements - not specifically English ones. The winning of the two world wars and the once globally powerful former British Empire were the most recurrent illustrations. As in the 1982 and 1986 World Cup, in 1998 and 2002 the Argentinean team was associated with the battle over the Falkland Islands in the British newspaper coverage. This has been mentioned in previous studies of press coverage of the 1998 and the 2002 World Cup Finals. [63] Headlines such as, 'Falklands Revenge', from the Daily Mirror in 2002, were still common and a photo in The Independent depicts British exservicemen and women in the Falklands. The caption that was underneath the photo pointed out that these ex-British servicemen and women were 'proud to support England'. Here fans were flying the Union flag as well as the St George Cross clearly showing how Englishness and Britishness are still often fused especially when England play teams from nations they have previously been at war with. [64]

Reports on British figureheads at England matches again acted to remind English readers they are British. For instance, Prince Harry was described in an article in the Daily Mail during the 1998 World Cup as 'getting into' the England versus Columbia match. [65] Further to this, the England team's first match of the 2002 World Cup occurred on the same day as Queen Elizabeth II celebrated her golden jubilee - fifty years as the British head of state. Although the ways in which the national press covered the coincidence of these two events has been briefly discussed by Garland, [66] it provided an excellent opportunity to see which event was given most prominence by the London based national newspapers one that was associated with England, or one that was connected with Britain. In many of the newspapers examined, England and Britain were still taken to mean the same thing. The Queen was reported as giving the England team a good luck message before their first match, and captain David Beckham was said to have used this as extra motivation to enhance the team's performance. Nevertheless, it is not clear whether he wanted to win for the nation, the state, or both: 'Let us play - Becks rallying call as nation parties over Cup and Jubilee', was an example of the sorts of headlines printed on this story. [67] Correspondingly about the Queen's message to the England team, an article in The Sun claimed '...many footie fans reckon that is a good omen for England to crown a successful tournament by bringing the Cup back for her maj'. [68] Visually, this newspaper combined the two events into one through displaying such things as a cartoon of the Queen and Prince Phillip, with a 
painting of what appears to be Henry VIII. There were no Union flags apparent anywhere here however, only those of St. George. [69]

It became obvious that Britain and England were being regarded as synonymous by many journalists over this weekend: 'With the Golden Jubilee adding to the feelings of national pride, cars and lorries sported English flags from their roofs and windows in an unashamed display of patriotism...Union Flags and Jubilee bunting went up in streets across the land'. [70] A further example highlights how England and Britain are seen as a single nation, instead of a nation and a state: 'England's Pride: Queen prays for victory as Beckham carries the nation's Jubilee dream'. [71] Yet, there was also recognition that England and Britain were different entities. For instance, the Daily Express dedicated a double page spread to an article entitled 'Happy Weekend Posh and Becks'. This was based upon the differences and similarities between Britain and England, the latter of which was embodied in David Beckham, and the former in Queen Elizabeth II: 'As the nation waves the Union Flag for our Queen and the standard of St. George for our team, we look at how these two patriotic moments were destined to collide'. [72] Similarly, a different article in one of the 'quality' newspapers argued that 'the country is divided by two forms of patriotism' and 'As these two allegiances come into conflict, we must ask which is the illusion, and which the reality'. [73] Furthermore, there were many visual signs of the English nation and the British state being distinguished in the newspapers studied during the 2002 World Cup. Perhaps one of the most blatant cases was found in the Daily Mail, which printed a photo of the Queen with the Union flag in the background taking up the whole of the front page; but also, on the whole of the back page, a photo of David Beckham with the St. George Cross in the background. [74]

Overall, it is clear to observe that the St. George Cross flag has definitely replaced the Union flag as the symbol of England since 1990. Whether this indicates a rise in a specifically English national consciousness is still questionable. The strength of devotion towards the British crown should not be underestimated even following the devolution of the UK in the later 1990s. There was a strong sense that the England team were playing for Britain and the Queen in all coverage of World Cup Finals studied between 1950 and 2006.

In addition to these findings, another facet of Englishness was also observed in British newspaper representations of the national team during World Cup Finals.

\section{The co-existence of local and regional identities with the idea of Englishness}

Bryant and Colls argue that although divided internally themselves, throughout history the Scots, Welsh and Irish have in general terms seen themselves in contradistinction to the English and have based their national identities upon a 'Celtic non-Englishness'. [75] For instance, Giulianotti argues that fans of the Scottish national football team (the 'Tartan Army') have consciously presented themselves in contradistinction to England and Englishness. [76] Yet as the English have traditionally been the most dominant nation within the UK, they have no strong unified opposition to the other home nations. As has been suggested so far in this essay, Englishness might be considered fragile because it has relied upon being synonymous with Britishness for so long that a specific English national identity can no longer be distinguished from British national identity. This means that local or regional identities within England may have the potential to fragment the somewhat fragile overarching idea of Englishness with which they co-exist. Borrowing Anderson's term for nations, Colls and Lancaster suggest that, 'regions, no less than nations, are imagined communities'. [77] The north-south divide in England is associated with a number of images and stereotypes which illustrate very different conceptions of Englishness mainly based around assumed social class divisions between the 'northern working class' and the 'southern political elite'. [78]

Historical literature on sport and identities within England has tended to focus on 'the north' as having an identity that contrasts to that of 'the south'. [79] Northern identity is regarded as different to English public school influenced ideals of Amateurism and Muscular Christianity as it is based around working-class industrial communities, such as mining 
communities in areas like the north east. [80] There is said to be more emphasis on winning, a more physical style of play including qualities of robustness and aggression that are respected as exceptionally northern qualities and embodied by northern sporting heroes.

[81] The north is often associated with sports that are not popular in the rest of the country. The best example is rugby league since the split with rugby union in 1895. Many saw this as a class related dispute between southern amateurs and northern professionals. [82]

Despite the literature on the north and sport, there is far less on the south of England and sport. However, Phelps has attempted to show that the image of northern sport depicted by such authors as Holt is nothing more than a stereotype built around perception and does not equate with evidence. [83] Stone has added some support to Phelps' claim through a survey conducted in 2002 of Surrey and Yorkshire county cricket fans. Findings suggested that both sets of northern and southern fans valued very similar player characteristics and could therefore not be separated by a north-south divide. [84]

The divisions amongst English people further fragment the broad categories of 'north' and 'south'. [85] For example, regarding the north-east of England, Purdue states: 'The last decades have seen an increasing tendency to use the term 'North-East' not just as a convenient geographic expression but as one indicating a sense of identity'. [86] Regional identity was considered so strong in north-east England that it could have led to an elected regional assembly with partially devolved powers being granted to the region in a 2004 referendum. Although this was emphatically rejected with almost eighty per cent voting against, [87] the north-east has strong links to northern sport and attitudes generally, but is also regarded by its inhabitants as being uniquely distinct from north-west counties. [88] Even within the north-west there are strongly felt differences between Yorkshire and Lancashire regarding the way cricket is played. [89] The rivalry is often linked to the war of the roses. Speaking of Yorkshire specifically, Russell suggested '...cricket provided arguably the major vehicle for the construction and negotiation of key elements of the county's identity'. [90] Yorkshire County Cricket Club have only relatively recently (since 1991) relaxed the rule stating that in order to play for Yorkshire you have to have been born there. [91]

Thus, even a cursory look at the history of sport literature demonstrates that sport has been involved in reinforcing local and regional identities that divide the English and coexist with the idea of an overarching English national identity, if not politically, then culturally at least. This was reflected in the world cup coverage analysed.

\section{'...the North will want to know why'}

The press continually referred to English players' and managers' local or regional identities within World Cup stories, especially if they were from northern parts of England. Whether intentional or not, this acted as a way for fans reading the stories to connect with the players more than merely representing them as 'English' would have allowed. This practice has perhaps thus far been taken for granted by academics and should be taken more seriously as an example of banal flaggings of the multiple identities that co-exist within England. Contrary to it being a response to recent processes of devolution, this practice has been engaged in by national newspapers since the first World Cup within which England were involved. A Frank Butler column in the News of the World during the 1950 World Cup held in Brazil stated '....one or two of the England players are a little homesick. One of them, looking at the semi-skyscrapers which have around 70 floors, remarked: "What's this place got that Blackpool hasn't?" And another chipped in: "l'll settle for Southend right now." It's the same the whole world over-there's no place like home'. [92] The practice of referring to prominent players by way of their local/regional identity was common throughout every year of the World Cup coverage analysed. In the Daily Express during the 1958 tournament, Desmond Hackett refers to the Preston North End hero Tom Finney by starting of his article with: 'Finney (Lancashire and down to football pitch earth)'; in another article later on during this World Cup Hackett refers to how, 'Charlton has never had his chance and the North will 
want to know why'; and, the same journalist refers to 'Bryan Douglas, the poker-faced little laddie from Lancashire' during the 1962 World Cup. [93]

This practice was also apparent in other tabloids later on. Both the tabloid and middle-market papers often seemed to highlight the north-east identities of players more than any others. For instance, from the 1980s The Sun and the Daily Mail often referred to key England players Bryan Robson and Paul Gascoigne by way of their north-east roots. In The Sun during the 1982 World Cup Robson is referred to as 'a tigerish young Geordie' and the Daily Mail refers to Bryan Robson's regional and local identities as important to him and reinforces north-east stereotypes with such passages as: "Wor Bryan", as his mother, Maureen, admits in her rich North-East accent', and, 'Robson's retiring nature can also be traced from the opulence of England's surroundings in Spain to a neat council 'semi' in Chester-le-Street - that hospitable slice of Co. Durham's mining community'. [94] Over the 1990 World Cup The Sun referred to 'The feud between the two Geordies' and later the 'fellow Geordies' in reference to Bobby Robson and Paul 'Gazza' Gascoigne. [95] 'Gazza' is also often specifically referred to as the 'Geordie lad' or 'the Geordie genius' and is quoted in The Sun as saying 'I am still the same lad who likes to drink with his mates in the Dunston Excelsior back on the North East'. [96] Later still, during the 1998 World Cup the Daily Mail presented a double page spread of photos of England's starting eleven as children. Underneath each the captions described what school teachers said about the players and the local communities in which the schools were situated, [97] giving an indication of the local identities of the players that readers could relate to.

English players and managers from other home nations teams were also routinely referred to in World Cup stories by way of their English local and regional identities. This somehow acted to make them seem more English than simply referring to them as 'English' would have done. The best examples can be found in relation to Jack Charlton, the former England World Cup winner who became manager for the Republic of Ireland national team during the 1990 World Cup. Charlton was always referred to in relation to his north-east identity in both The Sun and the Daily Mail. [98] The English birthplaces of players in his Republic of Ireland team were also often highlighted. In a report on England's game against the Republic of Ireland during the 1990 World Cup, an article in the Daily Mail claimed '...nobody else in the World Cup could have cared less that two teams of English League journeymen managed by a couple of Geordies drew last night', and then proceeded to go through the whole team picking out seven of thirteen players who were born in English towns and cities and learned to play football at English clubs. [99] One such player was highlighted more than most - Ireland's captain Mick McCarthy. An article in The Sun makes many references to McCarthy's northern English identity: 'McCarthy is now the Republic's captain, despite a Tyke accent as thick as a Barnsley slagheap and an upbringing spent fishing and walking on the Yorkshire Moors near his home'. [100]

From the 1980s it also became apparent that tabloid and middle-market papers were highlighting the local and regional identities of English fans in World Cup stories by either describing how they were choosing to portray their national identity or by stating where they were from. Both the Daily Mail and The Sun highlighted local and regional identities of fans in photos and messages wishing the England team well. On the front page of The Sun during the 1990 World Cup, three messages from fans from Essex, Central London and West Sussex, were chosen to represent the 'thousands of messages' sent in to the newspaper wishing the England team good luck. [101] Also, on the front page of the Daily Mail during the 1986 World cup a photo depicts England and Argentina fans with England fans holding a Union flag with 'HI WESTWAY' along the top, 'ENGLAND' across the middle and 'ALDERSHOT' at the bottom. In the main front page story accompanying this photo 'England out of World Cup: Beaten by the Magic Man', the journalist refers to 'A Union Jack printed with the name of Newcastle was tor up' by Argentine fans. [102] This provides some evidence that local identities were fused with support for the England team before devolution had occurred, and involved the use of the British Union Jack for this purpose, not just the specifically English St George Cross. 
These examples might act to demonstrate the southern bias in representations of fandom for the England team, yet reporters also often seemed to fabricate stories that supposedly drew upon the reactions of fans situated in northern towns and cities to England's progress in World Cups. For instance, the reaction of fans in Newcastle are referred to in the Daily Mail during the 1998 World Cup: 'Fans in Newcastle upon Tyne, who saw their Newcastle United hero David Batty miss his vital penalty shot, were particularly grief-stricken'. [103] In a similar fashion, whenever acts of hooliganism were reported as occurring in England, it was specific and well known towns and cities that were highlighted most prominently by the newspapers. For instance, during the 1990 World Cup violent reactions of fans to England losing to West Germany are reported in places like Brighton, London, Devon, Southampton and Birmingham. [104] Whether or not a southern bias was apparent, these newspapers felt it important to highlight the local and regional identities of fans so that readers could identify with them. This was more effective than simply referring to them as 'English' would have been.

\section{Conclusion}

The primary aim of this essay has been to highlight how the relationship between Englishness and football has been represented as multifaceted throughout British press coverage of the largest and most longstanding international football competition in the world. Although a specifically English national consciousness can be seen to be emerging in the newspapers analysed, it is clear to see that Englishness has never been depicted in one way and remains multi-faceted despite advancing European integration and related devolution of the UK.

English national identity was depicted as fused with Britishness throughout every year of coverage analysed, even though a more specific Englishness was portrayed through depictions of fans from the 1980s and a greater importance was placed on English football in the press after the 1966 World Cup win. This was further reinforced after the team progressed to the latter stages of the tournament in 1990. The fusion of England and Britain is nothing new - many authors have shown that it is impossible to separate English from British history. The point is that the evidence provided here suggests that this practice has been banally reinforced by the British press in their coverage of the England football team in World Cup Finals throughout history.

Added to this, local and regional identities of English players, managers and fans, particularly northern English identities, have always been highlighted in World Cup reporting and as such cannot be explained as some kind of English response to recent processes of European integration and devolution. Whether this is due to a southern bias in British national newspaper reporting requires further investigation. A weakness of this study is that the majority of newspapers analysed were London based. A future study into the representations of English national identity through World Cup coverage in regional versions of some of these national newspapers would provide a useful comparison. According to Rosie et al, every London based daily paper now prints an edition for readers in Scotland: 'Thus even when they buy the 'same' titles, readers in England and Scotland may find quite different editorial copy'. [105] The only problem with such a comparative analysis is that Scottish versions do not date back as far as the London based versions. However, regional dailies from various parts of England have often existed for longer than most national dailies and would therefore provide a useful source of comparison with the data provided here.

If national newspapers are regarded as a key source of information for football fans on the England team's progress in the World Cup Finals tournament throughout history, then the findings presented here may help explain current multifaceted articulations of Englishness on the part of current fans. However, the precise nature of the relationship between advanced European integration, devolution and the apparent shift in the large scale adoption of specifically English cultural symbols like the St George Cross at football matches, still needs to be determined. This cannot be achieved without asking football fans themselves about the significance and meaning underlying their displays of national identity. 
This is the final aspect of the author's wider project on the complexities of defining Englishness through football fandom practices.

\section{Notes}

[1] Herbert F. Moorhouse, 'One State, Several Countries: Soccer and Nationality in a 'United Kingdom', in James A. Mangan, ed., Tribal Identities: Nationalism, Europe, Sport (London, 1996), pp. 55-74.

[2] Ronald Price, 'Amateur Football - International Competitions', in Richard Cox, Dave Russell and Wray Vamplew, eds., Encyclopedia of British Football (London, 2002), pp. 22-23. Also see Brian Glanville, The Story of the World Cup (London, 1997); James Walvin, The People's Game: The History of Football Revisited (Edinburgh, 1994).

[3] See Barry Bowker, England rugby: a history of the national side, 1871-1976 (London, 1976); David Frith, Australia Versus England: A Pictorial History of Every Test Match Since $1877,12^{\text {th }}$ Edition (Melbourne, 2007).

[4] Dilwyn Porter, "Your boys took one hell of a beating!' English football and British decline, c.1950-80', in Adrian Smith and Dilwyn Porter, eds., Sport and national identity in the Post-war World (London, 2004), pp. 31-51; Jessica S. R. Robinson, 'Tackling the anxieties of the English: searching for the nation through football', Soccer \& Society, 9 (2) (2008), pp. 215-230.

[5] Bowker, England rugby; Frith, Australia Versus England.

[6] See Richard Giulianotti, Football: a Sociology of the Global Game (Oxford, 1999); Dave Russell, Football and the English: A Social History of Association Football, 1863-1995 (Preston, 1997); Robinson, 'Tackling the anxieties of the English', pp. 215-230.

[7] Mark Perryman, Ingerland: Travels with a Football Nation, (London, 2006), p.293; Anthony King, 'Nationalism and Sport', in Gerard Delanty and Krishan Kumar, eds., The Sage Handbook of Nations and Nationalism (London, 2006), pp. 249-259. 
[8] Christopher G. A. Bryant, 'These Englands, or where does devolution leave the English?' Nations and Nationalism, 9 (3) (2003), pp. 393-412. For a brief explanation of the situation in Northern Ireland see Kevin Davey, 'No Longer 'Ourselves Alone' in Northern Ireland, in David Morley and Kevin Robins, eds., British Cultural Studies (Oxford, 2001), 79-95.

[9] John Curtice, 'Is there an English backlash? Reactions to devolution', in Alison Park, John Curtice, Katarina Thomson, Miranda Phillips and Elizabeth Clery, eds., British Social Attitudes: the $25^{\text {th }}$ Report (London, 2009) pp. 1-23; Nick Groom, The Union Jack: A Biography (London, 2006).

[10] Jackie Abell, Susan Condor, Robert Lowe, Stephen Gibson and Clifford Stevenson, 'Who ate all the pride? Patriotic sentiment and English national football support, Nations and Nationalism, 13 (1) (2007), pp. 97-116.

[11] Tom Gibbons and Jim Lusted, 'Is St George enough? Considering the importance of displaying local identity while supporting the England national soccer team', Annals of Leisure Research, 10 (3/4) (2007), pp. 291-309.

[12] Russell, Football and the English, pp. 103-104.

[13] Ibid., p. 140; Fabio Chisari, "Definitely not Cricket': The Times and the Football World Cup 1930-1970', The Sports Historian, 20 (1), p. 49.

[14] ABC Figures 2006 cited in Liz Crolley and David Hand, Football and European Identity: Historical Narratives through the Press (London, 2006), p. 9; Colin SeymourUre, The British Press and Broadcasting since 1945 (Second Edition, Oxford, 1996), pp. 26-29.

[15] See Pablo Alabarces, Alan Tomlinson and Christopher Young, 'Argentina versus England at the France '98 World Cup: narratives of nation and the mythologizing of the popular', Media, Culture \& Society, 23 (5) (2001), pp. 547-566; Raymond Boyle and Cláudia Monteiro, 'A Small Country with a Big Ambition': Representations of Portugal and England in Euro 2004 British and Portuguese Newspaper Coverage', European Journal of Communication, 20 (2) (2005), pp. 223-244; Chisari, 'Definitely 
not Cricket'; Tim Crabbe, “The Public Gets what the Public Wants' England Football Fans, 'Truth' Claims and Mediated Realities', International Review for the Sociology of Sport, 38 (4) (2003), pp. 413-425; Crolley and Hand, Football and European Identity; Liz Crolley and David Hand Football, Europe and the Press (London, 2002); John Garland, 'The Same Old Story? Englishness, the Tabloid Press and the 2002 Football World Cup', Leisure Studies, 23 (1) (2004), pp. 79-92; John Garland and Mike Rowe, 'War Minus the Shooting?: Jingoism, the English Press, and Euro 96', Journal of Sport and Social Issues, 23 (1) (1999), pp. 80-95; Joseph Maguire and Emma Poulton, ‘European Identity Politics in Euro 96: Invented Traditions and National Habitus Codes', International Review for the Sociology of Sport, 34 (1) (1999), pp. 17-29; Joseph Maguire, Emma Poulton and Catherine Possamai, 'Weltkrieg III?: Media Coverage of England Versus Germany in Euro 96', Journal of Sport and Social Issues, 23 (4) (1999), pp. 439-454; Emma Poulton, 'New Fans, New Flag, New England? Changing News Values in the English Press Coverage of World Cup 2002', Football Studies, 6 (1) (2003), pp. 19-36.

[16] Crolley and Hand, Football and European Identity; Chisari, 'Definitely not Cricket'.

[17] Glanville, The Story of the World Cup.

[18] Jonathan Bignell, Media Semiotics: An Introduction, (Manchester, 1997); Michael Billig, Banal Nationalism, (London, 1995), p. 93.

[19] Ibid., p. 119.

[20] Tim Edensor, National Identity, Popular Culture and Everyday Life (Oxford, 2002), p. 78.

[21] Michael Rosie, John Maclnnes, Pille Petersoo, Susan Condor and James Kennedy, 'Nation Speaking unto nation? Newspapers and national identity in the devolved UK', The Sociological Review, 52 (4) (2004), pp. 437-458.

[22] See Edwin Jones, The English Nation: The Great Myth, (Stroud, 1998); Krishan Kumar, 'Empire and English nationalism', Nations and Nationalism, 12 (1) (2006), pp. 1-13; Krishan Kumar, The Making of English National Identity, (Cambridge, 2003). 
[23] Richard Holt, Sport and the British, (Oxford, 1989), p. 262. See Nick Groom, The Union Jack: A Biography (London, 2006), p. Xvi; Kumar, The Making of English National Identity, p.9.

[24] Crolley and Hand, Football and European Identity, pp. 30-31.

[25] News of the World, 2 July 1950, p. 10.

[26] Manchester Guardian, 16 June 1954, p. 9.

[27] Daily Express, 11 June 1958, p. 7.

[28] For example, Daily Express, 12 June 1958, p.14; Daily Mail, 16 June 1958, p.11; and, Manchester Guardian, 16 June 1958, p.4.

[29] For instance, some papers highlighted Jackie Milburn's role in formulating the Northern Ireland team's strategy for their game against Argentina. For example, see Manchester Guardian, 11 June 1958, p.4.

[30] Daily Express, Mon 11 June 1962, p. 10.

[31] Jeremy Paxman, The English: A Portrait of a People, (London, 1998).

[32] Daily Express, 20 July 1966, p. 17. A very similar cartoon is evident in The Times 12 July, 1966 according to Chisari, 'Definitely not Cricket', p. 54.

[33] Daily Express, 30 July 1966, p. 14.

[34] Crolley and Hand, Football, Europe and the Press, p. 28.

[35] E. M. C. Barraclough, Flags of the World, (London, 1971), p. 23.

[36] Daily Express, 19 July 1966, p. 15.

[37] The Sun, 22 July 1966, p. 10.

[38] Holt, Sport and the British, p. 262.

[39] The Sun, 25 July 1966, p. 5.

[40] The Sun, 12 July 1966, p. 1.

[41] The Sun, 1 Aug. 1966, p. 10.

[42] Perryman, Ingerland, p. 294.

[43] For example, in The Sun, 24 June 1982, p.7, there was a photo of a fan with a St George Cross sticker.

Version: 21 September 2010 
[44] The Sun, 26 June 1990, pp. 4-5; The Sun, 4 July 1990, p. 4.

[45] The Sun, 18 June 1990, p. 30.

[46] See Crolley and Hand, Football, Europe and the Press; King, 'Nationalism and Sport'.

[47] Daily Mail, 9 July 1990, p. 21; The Sun, 9 July, p. 3.

[48] The Sun, 16 June 1990, p. 28; The Sun, 4 July 1990, p. 33; The Sun, 16 June 1982, p. 26; Daily Express, 12 June 1958, p. 14.

[49] See Crolley and Hand, Football, Europe and the Press; King, 'Nationalism and Sport'.

[50] Crolley and Hand, Football, Europe and the Press, p. 20.

[51] The Times, 27 May, 1970 cited in Chisari, 'Definitely not Cricket', p. 62; News of the World, 7 June 1970, p. 20.

[52] Daily Mail, 8 June 1970, p.1.

[53] The Sun, 14 June 1982, p. 1

[54] The Sun, 15 June 1982, p. 26.

[55] Daily Mail, 20 June 1986, p. 1.

[56] The Sun, 3 July 1990, p. 1.

[57] Daily Mail, 4 July 1990, p. 47.

[58] The Sun, 5 July 1990, p. 3.

[59] The Daily Mail, 18 June 1990, p. 45, talks about good behaviour of Scottish fans which is a stark contrast to the English. A similar story appeared again later in the Daily Mail 27 June 1990, p. 5, which stated: 'The Scots drank and were friendly but the English are mental'.

[60] See Crabbe, 'The Public Gets what the Public Wants'; Garland, 'The Same Old Story?'; and, Poulton, 'New Fans, New Flag, New England?'

[61] Daily Express, 13 June 2002, p. 6.

[62] The Observer, 28 May 2006, pp. 16-17. 
[63] In relation to the 1998 World Cup see Alabarces et al, 'Argentina versus England at the France '98 World Cup'. In relation to the 2002 World Cup see Crabbe, 'The Public Gets what the Public Wants'; Garland, 'The Same Old Story?'; and, Poulton, 'New Fans, New Flag, New England?'

[64] Daily Mirror, 6 June 2002, p.4; The Independent, 8 June 2002, p. 3.

[65] Daily Mail, 29 June 1998, p. 6.

[66] Garland, 'The Same Old Story?'

[67] Daily Mirror, 31 May, 2002, p. 4.

[68] The Sun, 31 May 2002, p. 1.

[69] The Sun, 31 May 2002, p. 8.

[70] Daily Mail, 1 June 2002, p. 2.

[71] Sunday Express, 2 June 2002, p. 1.

[72] Daily Express, 1 June 2002, pp. 18-19.

[73] The Sunday Telegraph, 2 June 2002, p. 21.

[74] Daily Mail, 1 June 2002, p. 1 and p. 96.

[75] Christopher G. A. Bryant, 'These Englands, or where does devolution leave the English?' Nations and Nationalism, 9 (3) (2003), pp. 393-412'; and, Robert Colls, Identity of England (Oxon, 2002).

[76] Giulianotti, Football.

[77] Benedict Anderson, Imagined Communities: Reflections on the Origins and Spread of Nationalism, (London, 1991); Robert Colls and Bill Lancaster, '1992 Preface', in R. Colls and B. Lancaster, eds., Geordies: Roots of Regionalism (Second edition), (Newcastle, 2005) p. Xiv.

[78] See Dave Russell, Looking North: Northern England and the national imagination (Manchester, 2004). For a table listing stereotypical ‘northern' and ‘southern' English characteristics see Rob Shields, Places on the Margin: Alternative Geographies of Modernity (London, 1991), p. 231. 
[79] Mike Huggins, 'Sport and the social construction of identity in north east England, 1800 - 1914', in Neville Kirk, ed., Northern Identities, Historical Interpretations of 'The North' and 'Northernness' (Aldershot, 2000), p. 132.

[80] Harvey Taylor, 'Sporting Heroes', in Robert Colls and Bill Lancaster, eds., Geordies: Roots of Regionalism (Second edition) (Newcastle, 2005), 115-132.

[81] Richard Holt, 'Heroes of the North: sport and the shaping of regional identity', in Jeff Hill and Jack Williams, eds., Sport and Identity in the North of England (Keele, 1996), p. 139.

[82] Tony Collins, Rugby's Great Split: class, culture and the origins of Rugby League football (Second edition) (London, 2006).

[83] Nicholas Phelps, 'The Southern Football Hero and the Shaping of Local and Regional identity in the south of England', Soccer and Society, 2 (3) (2001), pp. 4457.

[84] Duncan Stone, 'Cricket's regional identities: the development of cricket and identity in Yorkshire and Surrey', Sport in Society, 11 (5) (2008), pp. 501-516.

[85] S. J. D. Green, 'Northern History and the History of the North: Forty Years on', Northern History, 42 (1) (2005), p. 22.

[86] A. W. Purdue, 'The History of the North-East in the Modern Period: Themes, Concerns and Debates since the 1960s', Northern History, 42 (1) (2005), p. 107.

[87] John Curtice, 'Is there an English backlash? Reactions to devolution', in Alison Park, John Curtice, Katarina Thomson, Miranda Phillips and Elizabeth Clery, eds., British Social Attitudes: the $25^{\text {th }}$ Report (London, 2009) pp. 1-23.

[88] Taylor, 'Sporting Heroes', p.132.

[89] Holt, 'Heroes of the North', p. 144.

[90] Dave Russell, 'Sport and Identity: The Case of Yorkshire County Cricket Club 18901939', Twentieth Century British History, 7 (2) (1996), p.207.

[91] Stone, 'Cricket's regional identities'.

[92] News of the World, 25 June 1950, p. 10.

Version: 21 September 2010 
[93] Daily Express, 7 June 1958, p. 12; Daily Express, 18 June 1958, p.12; Daily Express, 4 June 1962, p. 16.

[94] The Sun, 17 June 1982, p. 26; Daily Mail, 29 June 1982, p. 27.

[95] The Sun, 18 June 1990, p. 30; The Sun, 20 June 1990, p. 34.

[96] The Sun, 26 June 1990, p. 30.

[97] Daily Mail, 22 June 1998, p. 3.

[98] For instance he is referred to as 'the rough-hewn Geordie' in The Sun, 27 June 1990, p. 30; or as Bobby Robson's 'fellow Geordie' in the Daily Mail, 11 June 1990, p. 43.

[99] Daily Mail, 12 June 1990, p. 43.

[100] The Sun, 30 June 1990, p. 29.

[101] The Sun, 30 June 1990, p. 1.

[102] Daily Mail, 20 June 1986, p. 1.

[103] Daily Mail, 1 July 1998, p. 7.

[104] Daily Mail, 5 July 1990, p. 2.

[105] Rosie et al 'Nation Speaking unto nation?' p. 440. 